The Scream of the Young Burrowing Owl sounds like the Warning of the Rattlesnake

WhILE working upon the tertiary beds of the plains east of the Rocky Mountains recently, I bad numerous opportunities of making observations on the habits of those peculiar creatures the Burrowing Owls (Speotyto hypogaea). Among others made at the time is one relating to the extraordinary similarity between the sound of the cry of the young owl when disturbed, and that of the warning of the Rattlesnake (Crotalus confucentus), which I do not find to have been noticed by ornithologists. My attention was first called to the peculiar likeness by my friend, Dr. V. T. McGillicuddy, who had in his possession a couple of owlets nearly as large as the adults. The capture of a number of both snakes and birds enabled me by experiment to determine to what extent one might be deceived by the resemblance. At the distance of a few feet the shrill tremulous scream would deceive persons quite familiar with the sound of the rattling of the Crotalus. When not noticing or thinking of the birds, their cry produced on us the same effect as the sudden springing of the rattle by an angry snake. The experiments left no doubt that the cries produced a similar effect on other animals which unwittingly disturbed young owls. And in this way they led to a consideration of the possible benefit of this close resemblance, or, as it might be called by some, mimicry. As you know, the birds are fond of the deserted holes of different burrowing animals, especially so of those of various Spermophiles or Prairie Squirrels. They are common in and about colonies of the so-called "Prairie Dogs" (Cynomys ludovicianus), where they take possession of vacant burrows, and sometimes even of those in use, somer orlater dispossessing the rightful owners, as the dogs seemdisinclined to bring eyes and noses into contact with the sharp beaks and claws in the passages however familiar they may be with the birds around the mouths of the dwellings. In the same localities the snakes are numerous, and the squirrels form a considerable portion of their prey. Naturally enough the rodents-as also the weasels, foxes, and coyotes (Canis latrans)-dread the fangs and venom, and recognise and profit by the warning. May it not be that the peculiar protest or scream of the young $0 \mathrm{wl}$, by its resemblance to the dangersignal, insures safety by preventing the approach of the mammals, and, possibly, of the dull-eared snakes themselves? The scream of the old bird is rather more hoarse and somewhat less like the shrilling of the serpent. On ordinary occasions, the note of this owl is a cackling or chuckling chatter or laugh, varied with what seem very much like imitations of the barking and squealing of the squirrels. When caught, it gives utterance to the hoarse, long-drawn, rattling scream. The owlets ate greedily of fresh meat, stopping to utter their strange cry of alarm at every attempt to approach them. In behaviour the adults were similar, but much less tractable. One, which had his wing broken, was allowed the freedom of the camp, and usually he stowed himself under the waggon. A halt in a "dog-town" one day brought him near one of the holes, which after a time he discovered. At once his soldierly walk quickened; it became a quick step as he neared the opening. Chuckling to himself, down into the darkness he plunged, and that was the last we saw of him.

Cambridge, Mass., U.S.A., December 3

\section{Fertilisation of the Common Speedwell}

IF Mr. Ransom will refer again to my letter, he will see that it was written in o:der to draw attention to the adaptation of the flower for cross-fertilisation, and not especially to the fact that Diptera in settling upon it, draw down the stamens. This latter, if we consider the close attention paid of late years to the commoner Eurjpean wild flower; has in all probability been frequently observed before. As I have not seen Schenck's hand. book, I would be glad if Mr. Ransom will quote the passage to which he refers. On looking at my note-book I find that not only $V$. officinalis, but also $V$. Chamedrys and $V$. Beccabunga are shown as fertilised in the same manner. May I suggest that the separation of the stamens, and the difference of inclination between stamens and pistil, have been brought about in order to prevent self-fertilisation? The looseness of the corolla would then, in such a flower as $V$. Chamodrys, bring the anthers to a level with the stigma when an insect alighted upon it, and would thus promote cross-fertilisation. From want of $\mathrm{m}$ re extended o sservations, however, I could not say what would happen in the case of a proterogynous species, or of such a flower as $V$. spicata. In reply to Mr. Ransom, I may add that I have nowhere stated $V$. officinalis to possess larger flowers than $V$. hederofolia, and that Mr. Darwin ("Cross and Self-fertilisation," p. 369), in a brief reference to the genus, simply states that $V$. agrestis is self-fertilising, and mentions species of Syrphidæe as visiting the flowers of $V$. hederafolia and $V$. officinalis.

The Owens College, Manchester, December I5

\section{A. MACKENZIE STAPLEY}

\section{Complementary Colours at the Falls of Niagara}

IF Mr. Cross, whose letter on the above subject appears in Nature (vol. xxuli. p. I50), will make what is for hip a very short excursion from Boston to Niagara, he will see a very perfect and permanent illustration of contrast-colours. In the American fall, the pure, green, even sheet of water is "trimmed," as it were, at regular intervals by broad bands of foam, which although, of course, really white, appear of a delicate rose-pink hue. I noticed, and "made a note of this" ten years ago, and again this year. The effect heightens the beauty of the beautiful fall, and I am surprised that no poet has made capital out of it. I should like to call attention to the rapidity with which the Canadian fall is deepening its horse-shoe. An immense mass broke off near the middle of the curve in October, $x 874$ (many windows in the adjacent museum were broken by the concus. sion), and altogether the fall has receded twenty-four feet in ten years.

Eton College, December 15

H. G. MADAN

\section{DUMAS}

THE following is a translation of the addresses delivered in the Paris Academy of Sciences on the 4th inst., on occasion of a commemorative medal being presented to M. Dumas:-

'The President, M. Jamin, said: Gentlemen and dear Fellow-Members: The Academy considers it a duty to celebrate the golden wedding of those fellow-members who have honoured it during half a century, a duty which is always dear to us, but to-day is dearer than ever; for M. Dumas now completes his fiftieth Academic year. You have had prepared, by an able artist, a medal which happily recalls his features, and must perpetuate them; it bears on the back this inscription :

\section{A M. DUMAS \\ SES CONFRÈEs, SES Élìves, SES AMIS, SES ADMIRATEURS.}

I have nothing to add, except that it is not all his admirers, all his friends, all his scholars, but only those who sit here; the Academy has not been willing to share with any stranger the duty of a homage which it has exclusively reserved to itself. I have the honour to offer in your name, with respect, to our illustrious and venerated fellow-member, this token of our affection and of our gratitude.

My dear Teacher: If you will carry back your thoughts to the commencement of your career, you may well be content with your lot and with yourself. When twentytwo years of age, you were at Geneva; you began with Prevost, by discoveries that are still celebrated in physiology, on the urea, on the blood, and on generation. From that moment your name was known, and you acquired confidence in yourself. Then you perceived two things : the first, that physiology must be built upon chemistry, that chemistry was not made, and that it was necessary to make it; the second, that Geneva was not a large enough theatre for your projects. And so you came to Paris, having no other wealth than yourself, than your courage, than a programme resolutely determined; than the will to fulfil it, than confidence, still unconscious of the future that was promised you. Now the time has advanced, your dreams have been realised, your hopes exceeded, and you have reached the highest degree of glory a savant can conceive. Like Franklin, you may 
say: If I were to recommence my life, I could not seek anything better.

It is between that departure and this point of arrival that the most brilliant 'phase of your career is placed. Your discoveries followed one another like improvisations. The composition of ethers was unknown, you analysed them; you enunciated the law of substitutions and of the conservation of chemical types ; a constant preoccupation brought you frequently to the atomic theory, that fundamental base of chemistry; and you furnished, for measurement of the density of vapours, a method so simple and so perfect that it is easy to the most unskilful; we know what light it has thrown on the study of organic compounds. But it belongs not to me to speak of your innumerable researches. The scholar may not arrogate to himself, without irreverence, the right of praise or of criticism; in presence of the teacher, he has only the right of respect.

But it is permitted him to remember, and who does not remember, the charm and the marvels of your teaching at the Athénée, at the École Polytechnique, at the Sorbonne, at the École de Médicine, at the College de France, at the École Centrale? Everywhere that you have appeared, and you have appeared everywhere, youth and ripe age have been drawn, held, charmed, carried away, to such an extent, that it may be said that you have even rendered more service by the vocations you have decided, than by your own proper works.

Fifty years ago, this Academy opened her gates to you she has intrusted to you since, and ever congratulates herself for it, the formidable heritage of her illustrious per petual secretaries. The French Academy has seated you in the chair of Guizot, a professor like yourself ; but we have not been therefore jealous. They honoured you, and we did not lose you. Then comes the moment when preoccupations of another order have been imposed by your very renown; you have resigned yourself to those duties which enlarged your rôle, because your authority was necessary, because science mixes with all, because chemistry addresses itself to the lighting, sanitation, hygiène, and all the industrial requirements of a large city.

Circumstances have now set you free from manifold cares, and restored you to sciences and to letters. These possess you wholly; and whether it be art or industry, physics or chemistry, electricity or astronomy, it is to you people apply, it is your authority they seek. They find you ever ready for work, ever equal to the most difficult missions. When one recapitulates the work you have accomplished, the services of every kind you have rendered, the discoveries you have made, the lectures you have given in all the chairs, the literary works you have written, the ideas you have sown-all this existence, in fine, which has never known rest, one is astonished that you have not taken more than half a century to fulfil so large a programme; and when one has the happiness of seeing you and hearing you, one marvels that a halfcentury of labour without truce has still left you so much of youth to expend. It is because, of all human passions, that of study is the most healthy, because it leaves to the organs all their force, to the mind all its serenity-for it is wisdom.

Enjoy, my dear teacher, enjoy these fruits; all the good things that come from God have been given you without stint; genuine happiness, a health which nothing has affected, hearty good will towards all, a mental vision which has not ceased to grow; and all human recompenses have come to be superadded; an authority which makes itself felt and survives all régimes, a respect which disconcerts envy, and the affection of your fellow members which has prompted the gift of this medal : it is merely a small fragment of gold, but it will be precious to you, because it is amalgamated with our gratitude.

M. Dumas then spoke as follows:-
Mr. President and my dear Fellow-Members : Since my earliest steps in the way of science, the Academy has been to me the object of a reverence so profound that I cannot receive, without the most lively emotion, the inestimable present with which she honours the close of my career.

As far back as sixty years ago she gave a kindly attention to the work of my youth; half a century ago she received me in to her bosom; and since then she has not ceased to accord to me marks of her esteem and of her confidence; nothing had prepared me, however, to think that among my fellow members many should wish even now to call themselves my scholars. Of all the testimonies to which an old teacher might lay claim, the secret has been found of offering that one which is dearest to his heart. Your kindness overwhelms and confounds me !

Ah, my beloved scholars, I go back often enough to these thirty years of an apostolate, which has not been sterile, thanks to the talents of disciples like you ; but I believed the remembrance of it to be buried in the tomb of companions in the fight, whom we have lost, or to have passed from the memory of those who survive them. These prelections, then, of another time, of a time so happy, are still not forgotten, since you have wished to recall, in a durable way, on this medal, impressions that are ordinarily apt to be soon attenuated or even extinguished.

You are right! The Professoriate must be honoured, because speech is a power; because from the height of his public chair the professor fulfils a sacred mission. His loyal and penetrating conviction warms hearts, and raises minds towards the disinterested regions of the Ideal. He reflects the present state of science, like a faithful mirror, he prepares the discoveries of the future, he revives the grand traditions of a glorious past. Opening his whole heart and all his thought to his auditors, he teaches them to love the truth, to respect genius, to cherish the fatherland, and to serve it well.

Whoever has found himself surrounded by attentive youth, taking fire at the accents of the teacher, vibrating to his emotions, hastening full of faith towards the conquests indicated to its ardour, that man, believe me, has known the noblest enjoyments of the human soul.

But stay, there is a greater joy still; it is that experienced in seeing oneself outstripped by those to whom one formerly showed the way. This joy you have caused me to taste every day. May you, for the honour of French science, and for the moral greatness of our dear country, you who are of more value than I, have in your turn scholars who surpass you in genius, and equal you in heart.

Mr. President, and all of you my dear Fellow-Members, receive once more the profound expression of my grateful sentiments; the medal which I receive from your hands will be piously preserved by my family as the dearest of souvenirs of my existence, and by my descendants as the most honourable of titles of nobility.

\section{THE METEOROLOGICAL OBSERVATORY ON} $B E N$ NEVIS

THE importance of high-level stations in any satisfactory handling of the scientific and practical problems of meteorology which have now come prominently to the front, is everywhere recognised, and accordingly in almost all civilised countries such stations have been established, and their number is steadily increasing. On the continent of Europe, many of the more salient positions available for high-level stations are already occupied in France, Spain, Italy, Switzerland, Austria, Hungary, Germany, and Russia; and as regards other countries, the United States, Mexico, India, and our Australian colonies, have also established stations at great elevations, in an energetic prosecution of this important department 